\title{
Influence of strain and production cycle on egg quality traits of two Nigerian indigenous chicken strains
}

Oleforuh-Okoleh, V. U., Chukwuemeka, U. M. and Adeoye, G. O. Department of Animal Science, Rivers State University, Nkpolu-Oroworukwo, P. M. B. 5080, Port Harcourt, Nigeria

Abstract Corresponding author: vivian.oleforuh-okoleh@ust.edu.ng

Records obtained from purebred normal feather and naked neck Nigerian indigenous chicken strains were used to assess the influence of strain and production cycle on external and internal egg quality traits. The assessment commenced from first lay to 120 days of lay, classified into four production cycles (PC): PC1 (1-30 days of lays), PC2 (31-60 days of lays), PC3 (61-90 days of lays), and PC4 (91-120 days of lays). Mean egg weight, length and breadth were $4.34 \%$ heavier, $2.10 \%$ longer and $1.72 \%$ wider in the normal feather than in the naked neck ( $p<0.05)$. No disparity due to strain effect was found in egg shape index. Eggshells from the two strains had similar weight but varied in thickness with shells from the naked neck being $0.02 \mathrm{~mm}$ thicker than those from the normal feather $(p<0.05)$. Eggs from the normal feather were 7.13, 5.76, 5.00, 7.10 and 8.11\% superior in albumen weight, yolk height, albumen height, yolk index, and albumen index, respectively compared to its naked neck counterpart $(p<0.05)$. Production cycle significantly influenced all external egg quality studied. An increase of $16.21 \%$ in egg weight was obtained by PC4. Egg length and breadth increased consistently with each subsequent PC $(p<0.05)$ whereas egg shape index decreased with PC $(p<0.05)$. Higher values were recorded for yolk weight, yolk and albumen length and width in each subsequent production cycle. Haugh unit, yolk and albumen height had best values at PC2. Our findings indicate that strain type and production cycle highly influenced egg quality traits of Nigerian indigenous chickens with the normal feather showing superiority. Furthermore, the best internal quality was obtained at PC2 (31-60 days of lay). Our findings could be useful in choosing selection criterion traits in breeding plans for the development of different layer lines of normal feather and naked neck.

Keywords: Normal feather, naked neck, egg quality traits, production cycle, purebred, chickens

\section{Introduction}

The role of the Nigerian indigenous chicken in meeting the challenge of animal protein intake by the citizenry cannot be overemphasized. The Nigerian indigenous chicken has rich genetic reservoir, and is known to be highly adaptable and resistant to the harsh and adverse climatic and management conditions prevalent in the tropics. Within the past four decades, there have been numerous attempts on genetic improvement of the indigenous chicken by application of different breeding strategies (Nwosu, 1979; Omeje and Nwosu, 1984; Adebambo et al., 1999; Adediji et al., 2006;
Oleforuh-Okoleh, 2010; Adeleke et al., 2011). In 1994, indigenous chicken breed development project was launched at the Federal University of Agriculture, Abeokuta using different indigenous poultry breeds sourced all over Southwestern Nigeria, with the aim of developing pure lines, and improved Nigerian indigenous chickens (Adebambo, 2015). The purebred lines were obtained through intensive selection over six generation using body weight and egg production traits (egg number and egg weight) as selection criterion and pure breeding of the different strains. To 


\section{Egg quality traits of Nigerian indigenous chickens}

promote the production of this stock in other parts of the country as well as to integrate them into the existing commercial production milieu it is imperative to assess and document their performance outside their environment of origin. Such practice is upheld by the assertion of Nimbakar et al. (2008) that genetic improvement should cumulate in development of populations/flocks to meet both production and market conditions. This implies that the goal of improving the productivity of any breed/strain should be to integrate it into a viable and competitive economic market. Various studies on the Nigerian indigenous chicken infer that this chicken show greater potential as the laying type compared to the meat type chicken (Oleforuh-Okoleh, 2013; Ndofor-Foleng et al., 2015). Eggs are complete in their nutrient content and are the cheapest source of animal protein. The quality of the egg is of crucial concern in the efficiency of production and profitability of the egg production, processing and breeding industries, as well as the consumers' acceptability. Egg quality, the condition of the egg whether viable or table egg, is evaluated using traits associated with egg size, shell, yolk and albumen components. These traits are influenced by different genetic and non-genetic factors acting on several biochemical processes controlling them. The genetic factors could arise due to variations in gene actions such as those related to additive, dominance, pleiotropic, direct and maternal effects (Koerhuis et al., 1997; Hartmann et al., 2003; Monira et al.,2003), and some nongenetic factors associated with nutrition, production environment, health status, age of hen, etc. (Zaman et al., 2003; Vits et al., 2005; Rajkumar et al., 2009). Bain et al. (2016) noted that in improving strains/lines for egg production, the breeder prioritizes not only persistency in lay but also stability in egg quality over a longer period of time. The purpose of this study was, therefore, to assess the influence of strain and production cycle on egg quality traits of purebred normal feather and naked neck Nigerian indigenous chickens.

\section{Materials and methods Site of study}

This study was done at the Teaching and Research farm of the Department of Animal Science, Rivers State University, Port Harcourt between the months of July and November, 2016. The study site is located within longitude $6^{\circ} 55^{\prime}-7^{\circ} 56^{\prime} \mathrm{E}$ and latitude $4^{\circ} 75^{\prime} \mathrm{N}$. Port Harcourt is in the humid equatorial monsoon climatic region of Nigeria having a mean annual rainfall above $2300 \mathrm{~mm}$ with temperature ranges of $26-32^{\circ} \mathrm{C}$ and mean relative humidity of 6696\% (Edokpa and Nwagbara, 2017).

\section{Stock and management}

100 birds comprising normal feather (50) and naked neck(50) strain of Nigerian indigenous chicken maintained at the Unit were used for the study. These were progenies from selected parent stock of naked neck and normal feather Nigerian indigenous chicken obtained from about six generations of pure breeding and intensive selection, for improved body weight and egg production traits, at the Poultry Breeding Unit of the Teaching and Research farm of the Federal University of Agriculture, Abeokuta, Nigeria. The pullets were obtained at day-old and raised in deep litter pens using wood shavings as litter material for 18 weeks under ad libitum feeding regime using chick mash from day old to 8 weeks and growers mash from 8-18 weeks of age, using the recommendations of Oleforuh-Okoleh et al. (2016). At 18 weeks of age they were transferred from deep litter and assigned individually to cells in a three-tier battery cage. They were 


\section{Oleforuh-Okoleh, Chukwuemeka and Adeoye}

placed on ad libitum feeding regimen on layers' diet consisting of $17 \% \mathrm{CP}$ and

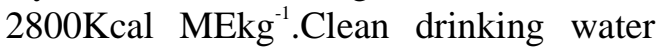
was also provided ad libitum throughout the study period. Vaccination was given against Newcastle, gumboro, fowl typhoid, fowl pox and fowl cholera according to the recommendations of National Veterinary Research Institute, Nigeria. Routine medications on vitamins and mineral supplements were also given.

\section{Measurement obtained}

Eggs were picked twice daily in the mornings (6.00-7.00hrs) and evenings (16.00-17.00hrs). Evaluation of egg quality traits was done from sexual maturity to 120 days of lay using two fresh eggs per hen on weekly basis. Consequently, 35 eggs were evaluated for each individual. Measurements were done on the following external egg quality traits: egg weight - this was done using a Mettler Toledo electronic sensitive weighing balance with $0.001 \mathrm{~g}$ accuracy; egg length - the distance from the broad end to the narrow end (along the longitudinal axis) and egg breadth - the circumference of the egg around the middle portion, that is, the equatorial axis were taken using a digital vernier caliper; egg shape index - ratio of the egg width to egg length expressed in percentage; shell weight - this was obtained after pouring the albumen and yolk into a white flat ceramic plate. The shell (with membrane) was gently and carefully washed to remove any adhering egg content, allowed to dry before the weight was obtained; shell thickness the shell thickness (with membrane) was obtained by taking the average of measurements (in $\mathrm{mm}$ ) made on the broad, middle and narrow end of the eggshell using a micrometer screw gauge.

To assess the internal quality traits, measurements of the contents poured into the white flat ceramic plate were then taken using a digital vernier caliper. Traits evaluated include - yolk and albumen height, length, and breadth. The values obtained were used to estimate the yolk and albumen indices as ratio of their respective length and breadth expressed in percentages (Kul and Seker,2004). The Haugh unit score was calculated as described in Oleforuh-Okoleh and Eze (2016). Yolk and albumen weight were obtained by carefully separating and placing the yolk and the albumen in different beakers, and their weight obtained with the sensitive weighing balance. Finally, to measure the yolk and albumen $\mathrm{pH}$, each of these contents was thoroughly mixed and their $\mathrm{pH}$ determined using a $\mathrm{pH}$ meter with 0.01 unit precision (Hanna Inst., Woonsocker, RI 02895).

\section{Data analysis}

The records obtained were summarized into four production cycles (days of lay from first egg) identified as - PCI (1-30), PC2 (31-60), PC3 (61-90), and PC4 (91-120). The multivariate analysis of GLM procedure (IBM SPSS, 2013) was used to carry out analysis of variance on all the data (using strain type and production cycle as fixed effects). Means were considered significantly different at $\mathrm{p}<0.05$ and separation was done using Duncan's option of the same software.

\section{Results and discussion}

The external egg quality traits of the naked neck and normal feather Nigerian indigenous chickens as influenced by the strain type and laying period is shown in Table 1. Variations $(p<0.05)$ due to strain effect were observed in egg weight, egg length, and egg breadth, whereas egg shape index was similar $(p>0.05)$ for the two strains. Mean egg weight of the two strains in the present study was found to be greater ( $4.34 \%$ heavier) in the normal feather chicken than in the naked neck $(\mathrm{p}<0.05)$. 
Egg quality traits of Nigerian indigenous chickens

Table 1: Effect of strain and laying period on external egg quality traits of Nigerian indigenous chickens

\begin{tabular}{lllllll}
\hline Traits & EW $(\mathrm{g})$ & $\mathrm{EL}(\mathrm{cm})$ & $\mathrm{EB}(\mathrm{cm})$ & $\mathrm{ESI}(\%)$ & $\mathrm{ST}(\mathrm{mm})$ & $\mathrm{SW}(\mathrm{g})$ \\
\hline Strain & & & & & & \\
Naked neck & $46.28^{\mathrm{b}}$ & $5.11^{\mathrm{b}}$ & $3.99^{\mathrm{b}}$ & 78.37 & $0.29^{\mathrm{a}}$ & 5.67 \\
Normal feather & $48.38^{\mathrm{a}}$ & $5.22^{\mathrm{a}}$ & $4.06^{\mathrm{a}}$ & 77.81 & $0.27^{\mathrm{b}}$ & 5.45 \\
SEM & 0.61 & 0.03 & 0.02 & 0.32 & 0.01 & 0.08 \\
$p$-value & 0.001 & 0.000 & 0.000 & 0.085 & 0.05 & 0.732 \\
Production cycle (days) & & & & & & \\
$1-30$ & $42.43^{\mathrm{c}}$ & $4.96^{\mathrm{d}}$ & $3.89^{\mathrm{c}}$ & $78.55^{\mathrm{a}}$ & $0.24^{\mathrm{c}}$ & $5.04^{\mathrm{c}}$ \\
$31-60$ & $48.33^{\mathrm{b}}$ & $5.16^{\mathrm{c}}$ & $4.06^{\mathrm{b}}$ & $78.84^{\mathrm{a}}$ & $0.25^{\mathrm{c}}$ & $5.85^{\mathrm{b}}$ \\
$61-90$ & $48.55^{\mathrm{b}}$ & $5.25^{\mathrm{b}}$ & $4.06^{\mathrm{b}}$ & $77.41^{\mathrm{b}}$ & $0.29^{\mathrm{b}}$ & $5.72^{\mathrm{b}}$ \\
$91-120$ & $50.64^{\mathrm{a}}$ & $5.34^{\mathrm{a}}$ & $4.12^{\mathrm{a}}$ & $77.22^{\mathrm{b}}$ & $0.32^{\mathrm{a}}$ & $5.91^{\mathrm{a}}$ \\
SEM & 0.70 & 0.03 & 0.02 & 0.42 & 0.01 & 0.09 \\
$p$-value & 0.000 & 0.000 & 0.000 & 0.000 & 0.000 & 0.000 \\
\hline $\begin{array}{l}\text { abc Means on the same column, for each } \\
\text { indicated. }\end{array}$ & \multicolumn{7}{c}{$\boldsymbol{p}$ effect, followed by different superscripts are significantly different at } & $\boldsymbol{p}$-values \\
\end{tabular}

Our finding was contrary to Udoh et al. (2012) and Egahi et al. (2013) who reported about $8.33 \%$ and $29.62 \%$ heavier eggs, respectively in naked neck Nigerian local chickens compared to their normal feather counterparts. Eggs from both strains were however heavier than $38 \mathrm{~g}$ reported by Oleforuh-Okoleh et al. (2012) after three generations of selection in a population of Nigerian light local chicken ecotype. Eggs from the normal feather were $2.10 \%$ longer and $1.72 \%$ wider than naked neck eggs. This was contrary to Yakubu et al. (2008) on superior length and width in the naked neck Nigerian indigenous chicken but upholds the findings of Kgwatalala et al. (2016) on longer and wider eggs in normal feather chickens in comparison to the naked neck. Differences in egg length and egg breadth as seen in this study affirms the submissionsof Anderson et al. (2004) and Markos et al. (2017) that these traits are influenced by genetic variations. The superiority observed in the normal feather was not expected given the reports of earlier studies by Peters et al. (2004) and Yakubu et al. (2008). These authors associated better performance of the naked neck to their possession of thermoregulatory genes which gave them greater adaptation to the hot humid tropical environment. It is imperative to note that our study was done during the peak of rainy season and such environmental condition could have been an added advantage for the superiority of the normal feather.

There was no disparity $(p>0.05)$ in egg shape index of the two strains, which ranged from $77.81-78.38 \%$. Our result was higher than $74.63 \%$ obtained by Oleforuh-Okoleh (2016) from a population of Nigerian native chickens but quite close to the value (76.00\%) reported by Ewa et al. (2005) in some exotic chicken strains. The similarity, in egg shape index between the naked neck and normal feather is in line with Iraqi (2002). Peters et al. (2007) however indicated that the naked neck hens produced eggs with better egg shape index than the normal feather. Though North and Bell (1990) suggested that the ideal egg shape index is $74 \%$, our values still indicated that eggs from both strains were oval in shape which ought to be the perfect shape of a chicken egg. Cavero et al. (2011) noted that egg shape index is an important trait in poultry breeding and table egg production 


\section{Oleforuh-Okoleh, Chukwuemeka and Adeoye}

since rounder eggs tends to have poor hatchability and egg grading status. The mean shape index of the two strains was within the recommended index for packaging in classic commercial cartons (Chatterjee et al., 2007).

Eggshells from the two strains had similar weight $(p<0.05)$ but varied in thickness with shells from the naked neck being on average $0.02 \mathrm{~mm}$ thicker than those from the normal feather $(p<0.05)$. The mean shell thickness of $0.29 \mathrm{~mm}$ obtained in the naked neck chickens is similar to the value obtained by Tadesse et al. (2015) and Abdurehman and Urge (2016) from Potchefstroom Koekoek, an indigenous South African chicken, and from ruralchicken in Gorogutu district, Eastern Hararghe, Ethiopia respectively.

Our findings on the external egg quality traits with respect to production cycles affirmed the reports of Silversides et al. (2006) and Tůmorvá and Gous (2012) that the age of the hen/laying cycle affects egg quality. Egg weight was least during PC1 but showed $16.21 \%$ improvement by PC4. Haunshi et al. (2011) also observed that egg weight increased as the period of lay (age) of the hen increased. Generally, our result indicates that eggs from both purebred Nigerian indigenous chickens can be classified as small within the first 30 days of lay and subsequently as medium size using the USDA average egg weight scale. Egg length and breadth increased consistently with age $(p<0.05)$ and confirms the observations made by John-Jaja et al. (2016) in Nera Black chickens raised in Nigeria. Though egg shape index reduced as production cycle increased $(p<0.05)$, much of the variation existed between the first two cycles (PC1 and PC2) and the last two cycles (PC3 and PC4). Johnston and Gous (2007) suggested that variations in the geometry of the egg as the hen ages could be linked with the changes in the weight/size of oviduct. Eggshell quality (weight and thickness) improved as the hens aged $(p<0.05)$. Shell thickness is important in egg grading since cracked or broken eggshells are of economic concern since they are often unacceptable by consumers and the hatchery industry resulting to huge monetary losses. Some authors inferred that eggs with shell thickness less than $0.33 \mathrm{~mm}$ are subject to ease entrance of microbes and breakage. Our study indicates that by $\mathrm{PC} 3$, the eggs had achieved shell thickness of $0.32+0.01$. This suggests that breeding at an earlier age could negatively affect hatchability due to poor shell quality.

Effects of strain and production cycle on yolk and albumen quality traits are illustrated in Tables 2 and 3, respectively. Eggs from the normal feather were 7.13, $5.76,5.00,7.10$ and $8.11 \%$ superior in albumen weight, yolk height, albumen height, yolk index, and albumen index respectively compared to their naked neck counterpart $(\mathrm{p}<0.05)$. Superiority of the normal feather to the naked neck on these traits was also reported by Kgwatalala et al. (2016). The variations observed could be attributed to genetic variations between the two strains since both where subjected to identical management practices (Niranjan et al., 2008; Haunshi et al., 2011). 
Egg quality traits of Nigerian indigenous chickens

Table 2: Effects of strain and production cycle on yolk quality traits of Nigerian indigenous chickens

\begin{tabular}{lccllll}
\hline Traits & $\mathrm{YW}(\mathrm{g})$ & $\mathrm{YH}(\mathrm{cm})$ & $\mathrm{YL}(\mathrm{cm})$ & $\mathrm{YB}(\mathrm{cm})$ & $\mathrm{YI} \%$ & $\mathrm{YpH}$ \\
\hline Strain & & & & & & \\
Naked neck & 15.09 & $1.47^{\mathrm{b}}$ & 4.09 & 4.07 & $38.61^{\mathrm{b}}$ & 6.46 \\
Normal feather & 15.04 & $1.56^{\mathrm{a}}$ & 4.04 & 3.82 & $41.56^{\mathrm{a}}$ & 6.40 \\
SEM & 0.286 & 0.023 & 0.045 & 0.016 & 0.744 & 0.076 \\
p-value & 0.851 & 0.000 & 0.247 & 0.127 & 0.001 & 0.383 \\
Production cycle (days) & & & & & & \\
$1-30$ & $13.17^{\mathrm{d}}$ & $1.49^{\mathrm{b}}$ & $3.79^{\mathrm{b}}$ & $3.55^{\mathrm{c}}$ & $41.13^{\mathrm{b}}$ & $7.15^{\mathrm{a}}$ \\
$31-60$ & $14.19^{\mathrm{c}}$ & $1.70^{\mathrm{a}}$ & $3.80^{\mathrm{b}}$ & $3.61^{\mathrm{b}}$ & $47.14^{\mathrm{a}}$ & $6.40^{\mathrm{b}}$ \\
$61-90$ & $15.88^{\mathrm{b}}$ & $1.42^{\mathrm{c}}$ & $4.29^{\mathrm{a}}$ & $4.06^{\mathrm{a}}$ & $35.39^{\mathrm{c}}$ & $6.17^{\mathrm{c}}$ \\
$91-120$ & $16.74^{\mathrm{a}}$ & $1.51^{\mathrm{b}}$ & $4.31^{\mathrm{a}}$ & $4.07^{\mathrm{a}}$ & $36.84^{\mathrm{c}}$ & $6.06^{\mathrm{c}}$ \\
SEM & 0.329 & 0.027 & 0.046 & 0.218 & 1.057 & 0.081 \\
$p$-value & 0.000 & 0.000 & 0.000 & 0.009 & 0.000 & 0.000 \\
\hline abcMeans on the same column,for each effect, with different superscripts are significantly different at $p$-values indicated.
\end{tabular}

Though the yolk index of both strains were lower than the values obtained by Fayeye $e t$ al. (2005) in Nigerian Fulani-ecotype chicken, but were still within the acceptable range of $33-50 \%$ given by Ihekoronye and Ngoddy (1985). The mean yolk and albumen $\mathrm{pH}$ from both strains were similar and within the normal value reported by Heath (1977) and Waimaleongra-Ek et al. (2009) for newly laid eggs. A non-significant strain effect was found on yolk weight, Haugh unit, yolk and albumen length, breadth and $\mathrm{pH}$. Similar finding on yolk weight and albumen breadth of naked neck and normal feather Nigerian chicken eggs was reported by Udoh et al. (2012). Haugh unit is a key criterion in evaluating egg quality. Though Silversides et al. (2006) detected strain differences in this trait, such variations were not recorded in the present study. Average Haugh unit of 79.04 obtained from the naked neck was within the range reported by Padhi et al. (1998) for naked neck Desi breeds, while the $80.24 \%$ recorded in the normal feather was similar to the value obtained in Kadaknath breed of India (Parmar etal. 2006).

Table 3: Effect of strain and production cycle on albumen quality traits of Nigerian indigenous chickens

\begin{tabular}{|c|c|c|c|c|c|c|c|}
\hline Traits & $\mathrm{AW}(\mathrm{g})$ & $\mathrm{AH}(\mathrm{mm})$ & $\mathrm{AL}(\mathrm{mm})$ & $\mathrm{AB}(\mathrm{mm})$ & $\mathrm{AI}(\%)$ & $\mathrm{A}_{\mathrm{P}} \mathrm{H}$ & $\mathrm{HU}(\%)$ \\
\hline \multicolumn{8}{|l|}{ Strain } \\
\hline Naked neck & $24.22^{\mathrm{b}}$ & $5.71^{\mathrm{b}}$ & 8.80 & 6.64 & $7.70^{b}$ & 8.05 & 79.04 \\
\hline Normal feather & $26.08^{a}$ & $6.23^{\mathrm{a}}$ & 8.65 & 6.50 & $8.30^{\mathrm{a}}$ & 8.03 & 80.24 \\
\hline SEM & 0.431 & 0.013 & 0.136 & 0.118 & 0.270 & 0.02 & 0.867 \\
\hline$p$-value & 0.000 & 0.014 & 0.291 & 0.234 & 0.026 & 0.240 & 0.166 \\
\hline \multicolumn{8}{|c|}{ Production cycle (days) } \\
\hline $1-30$ & $21.99^{c}$ & $5.96^{\mathrm{b}}$ & $7.89^{d}$ & $5.89^{\mathrm{b}}$ & $8.85^{\mathrm{b}}$ & $8.07^{\mathrm{a}}$ & $81.85^{\mathrm{a}}$ \\
\hline $31-60$ & $26.85^{\mathrm{a}}$ & $6.37^{\mathrm{a}}$ & $8.21^{\mathrm{c}}$ & $6.14^{\mathrm{b}}$ & $9.12^{\mathrm{a}}$ & $8.04^{\mathrm{ab}}$ & $82.48^{\mathrm{a}}$ \\
\hline $61-90$ & $25.80^{\mathrm{b}}$ & $5.54^{\mathrm{c}}$ & $9.09^{b}$ & $7.05^{\mathrm{a}}$ & $7.01^{\mathrm{b}}$ & $8.02^{\mathrm{b}}$ & $77.14^{\mathrm{b}}$ \\
\hline $91-120$ & $26.68^{\mathrm{ab}}$ & $5.78^{\mathrm{bc}}$ & $9.50^{\mathrm{a}}$ & $7.02^{\mathrm{a}}$ & $7.03^{b}$ & $8.03^{\mathrm{ab}}$ & $78.06^{\mathrm{b}}$ \\
\hline SEM & 0.516 & 0.170 & 0.016 & 0.139 & 0.380 & 0.027 & 1.127 \\
\hline$p$-value & 0.000 & 0.000 & 0.000 & 0.000 & 0.000 & 0.045 & 0.000 \\
\hline
\end{tabular}


All yolk and albumen traits studied were highly influenced $(p<0.05)$ by the production cycle. Higher values of yolk weight, yolk and albumen length and width were recorded with each subsequent period. Zita et al. (2013) made similar observations in a population of brown egg laying hens. No peculiar trend was observed in yolk and albumen height, however higher values $(1.70 \mathrm{~cm}$ and $0.64 \mathrm{~cm}$, respectively) were obtained at PC2. Albumen index within the period studied was lower than the estimate obtained by Dormus et al. (2010) in a Colombian chicken flock, and ranged from $7.03-9.12 \%$. Eggs produced at PC2 had the best internal quality as exhibited by the albumen index $(9.12 \%)$ and Haugh unit score $(82.48 \%)$. Our findings showed an obvious decrease $(4.42 \%)$ in Haugh unit between PC2 and PC4. The decrease in Haugh unit with age of the hen is in line with Ledvinka et al. (2012) and Tůmorvá and Gous (2012). Variations in $\mathrm{pH}$ value of the yolk and albumen has been associated with factors which influences oxygen consumption, carbondioxide loss through the shell pores, metabolic water and heat production. Decrease in yolk and albumen $\mathrm{pH}$ in subsequent periods of lay from $\mathrm{PC} 1$ in this study affirms the report of HosseiniSiyar et al. (2007) that albumen $\mathrm{pH}$ of eggs from younger hens was higher than those from older hens.

\section{Conclusion}

Our study indicated that strain type and production cycle influenced most of the egg traits studied, with the normal feather showing superiority over the naked neck. It also suggests that the best internal quality with respect to the yolk and albumen traits was obtained from eggs produced between 31-60days of lay (PC2). The information obtained from our study would be relevant when considering selection criterion traits for breeding programmes aimed at developing different layer lines of the Nigerian indigenous chicken. We recommend that further study on genetic evaluation of these traits be carried out to understand their mode of inheritance.

\section{References}

Abdurehman, A. and Urge, M. 2016. Evaluation of fertility, hatchability and egg quality of rural chicken in Gorogutu District, Eastern Haraghe, Ethiopia.Asian Journal of Poultry Science, 10:483-492.

Adebambo, O. A. 2015. From PEARL project to ACGG in Nigeria.A paperpresentedat the $F i r s t$ ACGG Nigeria Innovation Platform meeting, Ibadan, Nigeria, 20-22 July, 2015.

Adebambo, O. A., Ikeobi, C. O. N., Ozoje, M. O., Adenowo, J. A. and Oshinowo, O. A. 1999. Colour variation and performance characteristics of the indigenous chickens of $\mathrm{S}$ ou th-We s t Nigeria. Nig. J. of Anim. Prod.,26:15-22.

Adedeji, T. A., Adebambo, A. O., Ozoje, M. O. Ojedapo, L. O. and Ige, A. O.2006. Preliminary results of short-term egg laying performance of pure and crossbred chicken progenyina $\quad h \quad u \quad m \quad i \quad d$ environment. Journal of Animal and Veterinary Advances,5: 570573.

Adeleke, M. A., Peters, S. O., Ozoje, M. O., Ikeobi, C. O. N., Bamgbose, A. M. and Adebambo, O. A. 2011. Growth performance of Nigerian local chickens in crosses involving an exotic broiler breeder. Tropical Animal Health and 
Production, 43:643-650.

Anderson, K. E., Tharrington, J. B., Curtis, P. A. and Jones, T. 2004. Shell characteristics of eggs from historic strains of single comb white leghorn chickens and the relationship of egg shape to shell strength. Journal of Poultry Science, 3:17-18.

Bani, M. M., Nys, Y. and Dunn, I. C. 2016.Increasing persistency in lay and stablising egg quality in longer laying cycles. What are the challenges? British Poultry Science, 57:330-338.

Cavero, D., Schmutz, M., Icken, W. and Preisinger, R. 2011. Improving hatchability in white egg layer strains through breeding.Lohmann Information, 46:44-54.

Chatterjee, R. N., Rai, R. B., Kundu, A., Senani, S. and Sundar, J. 2007. Egg quality traits in indigenous breeds of chicken of Andaman.Indian Veterinary Journal,84:206-208.

Dormus, I., Kamanl, S., Demirtas, S. E. and Demir, S. 2010. The egg quality characteristics of Barred Rock-1, Rhode Island RedColombian.Lalahan-HayvanclkArastrma- Enstitusu-Derg.,50: 3339.

Edokpa, D. O. and Nwagbara, M. O. 2017. Atmospheric stability pattern over Port Harcourt, Nigeria.Journal of Atmospheric Pollution.5: 9-17.

Egahi, J. O., Dim, N. I. and Momoh, O. M. 2013. The effect of plumage modifiergenes on egg quality indices of the Nigerian local chicken.IOSR Journal of Agriculture and Veterinary Science,2:4-6.
Ewa, V. U., Otuma, M. O. and Omeje, S. I. 2005. Interrelationship of external egg quality traits of four i n b red line chickens strains.Tropical Journal of Animal Science, 8:23-36.

Fayeye, T. R., Adeshiyan, A. B. and Olugbami, A. A. 2005. Egg traits, hatchability and early growth performance of the Fulani-ecotype chicken.Livestock Research for $\begin{array}{llllll}R & u & r & a & l\end{array}$ Development.Volume17,Art.\#94.h ttp://www.lrrd.org//rrd17/8/faye 17 094.htm

Hartmann, C., Johansson, K., Strandberg, E. and Rydhmer, L. 2003. Genetic correlations between the maternal genetic effects on chick weight and the direct genetic effects on egg composition traits in white leghorn line.Poultry Science, 82:1-8.

Haunshi, S., Niranjan, M., Shanmugam, M., Padhi, M. K., Reddy, M. R., Sunitha, R., Rajkumar, U. and Panda, A. K. 2011. Characterization of two Indian native chicken b r e e d s for production, egg and semen quality, and welfare traits. Poultry Science,90:314-320.

Heath, J. L. 1977. Chemical and related osmotic changes in egg albumen during storage. $P$ o $\quad u \quad l \quad t \quad r \quad y$ Science, 56: 822-828.

HosseiniSiyar, S. A., Aliarabi, H., Ahmadi, A. and Ashori, N. 2007. Effect of different storage conditions and hen age on egg quality parameters.Aust. Poult. Sci. Symp.106-109.

IBM SPSS. 2013. Statistical Package for Social Science (SPSS) for window release: Version 22.0. 
Ihekoronye, A. T. and Ngoddy, P. O. 1985. Integrated food science technology for the tropics. Macmillan press Ltd. London.

Iraqi, M. M. 2002. Genetic evaluation for egg quality traits in crossbreeding experiment involving Mandarah and Matrouh chickens using animal model.Egyptian Poultry Science, 22:711-726.

John- Jaja, S. A., Abdullah, A. R., Nwokolo, S. C. 2016. Effects of age variance on repeatability estimates of egg dimensions of Bovan Nera Black laying chickens. Journal of Genetic,

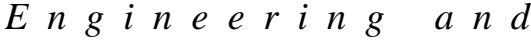
Biotechnology, 14:219-226.

Johnston, S. and Gous, R. 2007. Modelling the changes in the proportions of the egg components during a laying cycle.British Poultry Science, 48:347-353.

Kgwatalala, P. M., Molapisi, M., Thutwa, K., Sekgopi, B., Selemoge, T. P. and Nsoso, S. J. 2016. Egg quality characteristics and phenotypic correlations among egg quality traits in the naked neck, normal and dwarf strains of Tswana chickens raised

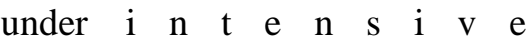
management system. International Journal of Environmental \& Agriculture Research,2:96105.

Koerhius, A. N. M., McKay, J. C., Hill, W. G. and Thompson, R. 1998. A genetic analysis of egg quality and their maternal influence on offspring-paternal regression of juvenile body weight in broiler chickens. Livestock Production Science, 49: 203-215.

Kul, S. and Seker, I. 2004. Phenotypic correlations between some external and internal egg quality traits in the Japanese quail (Coturnix coturnix japonica). International Journal of Poultry Science, 3:400-405.

L edvinka, Z ., Tum ova, E., Englma i rova, M. and Podsednicek, M. 2012. Egg quality of three laying hen genotypes kept in conventional cages and on litter. Archive fur Geflugelkunde,76:38-43.

Markos, S., Belay, B. and Astatkie, T. 2017. Evaluation of egg quality traits of three indigenous chicken e c o t y pes kept under farmers'management conditions. International Journal of Poultry Science, 16: 180-188.

Monira, K. N., Salahuddin, M. and Miah, G. 2003. Effect of breed and holding period on egg quality $\mathrm{c} \mathrm{haracteristics}$ of chicken.International Journal of Poultry Science, 2: 261-263.

Ndofor-Foleng, H. M., OleforuhOkoleh, V., Musongong, G. A., Ohageni, J. I., Duru, U. E. 2015. Evaluation of growth and reproductive traits of Nigerian local chicken and exotic chicken. Indian Journal of Animal Research,49: 155-160.

Nimbkar, C., Gibson, J., Okay, M., Boettene, P. and Solemner, J. 2008. Sustainable use and genetic improvement.Animal Genetic Resources, 42:49-69.

Niranjan, M., Sharma, R. P., Rajkumar, U., Chatterjee, R. N., Reddy, B. L. N. and Battacharya, $T$. K . 2008. Egg quality traits in chicken varieties developed for backyard poultry farming in $\quad \mathrm{I} \mathrm{d} \mathrm{i} \mathrm{a}$. 
Livestock Research for Rural Development. Volume 20,Article \#189.http://www.lrrd.org/lrrd20/1 2/nira20189.html.

North, M. O. and Bell, D. D. 1990. Commercial chicken production manual.AnAvi Book, $4^{\text {th }}$ Ed. Van Nostrand Reinhold, New York, USA.

Nwosu, C. C. 1979. Characterization of the local chicken of Nigeria and its potential for egg and meat production. Proc. $I^{\text {st }}$ National seminar on Poultry Production. National AnimalP ro d u c $t$ i o $n$ Research Institute Zaria, Nigeria. 1:187-210.

Oleforuh-Okoleh, V. U. 2010 . Improvement in egg production traits in the light local chicken ecotype using a selection index. $\mathrm{PhD}$ Thesis. Department of Animal Science, University of Nigeria, Nsukka.

Oleforuh-Okoleh, V. U., Nwosu, C. C., Adeolu, A. I., Udeh, I., Uberu, C. P. N. and Ndofor-Foleng, H. M. 2012. Egg production performance in a Nigerian local chicken ecotype subject to selection. Journal of Agricultural Science, 4: 180-186.

Oleforuh-Okoleh, V. U. 2013. Genetic gains from within-breed selection for egg production traits in Nigerian local chicken. Journal of Agricultural and Biological Sciences,8:788-792.

Oleforuh-Okoleh, V. U. 2016. Hatchability prediction in chickens using some external eggquality traits.Asian Journal of Animal Sciences, 10: 159-164.

Oleforuh-Okoleh, V. U. and Eze, J. 2016. Effect of storage period and method o $n \quad$ i $n \mathrm{t}$ e $\mathrm{rna} l$ e $\mathrm{g} g$ quality traits of the Nigerian native chicken. Livestock Research for Rural Development. Volume 28, Article\#115.

Oleforuh-Okoleh, V. U., Nte, I. J. and Onyegbule, Q. 2016. Growth $\mathrm{p}$ e $\mathrm{r}$ f o r m a $\mathrm{n} \mathrm{c}$ e a $\mathrm{nd}$ haematological traits of Nigerian local chickens fed varied dietary protein levels. Nig. J. Anim. Prod., 43:332-342.

Omeje, S. S. I. and Nwosu, C. C. 1984. Mode of inheritance and interrelationship of age and body weight at first egg and other short term production parameters in local and exotic crossbred chicken. Proceedings of the 17th World's Poultry Congress. Helsinki, Finland, 13:991-793.

Padhi, M. K., Rai, R. B., Senani, S. and Saha, S. K. 1998. Assessment of egg quality in different breeds of chicken.Indian Journal of Poultry Science,33: 113-115.

Parmar, S. N. S., Thakur, M. S., Tomar, S. S. and Pillai, P. V. A. 2006. Evaluation of egg quality traits in indigenous Kadaknath breed of poultry.Livestock Research for Rural Development.Volume 18, $\begin{array}{lllllll}A & r & t & i & c & l & e\end{array}$ \#132.http://www.lrrd.org/lrrd18/9/ parm18132.htm.

Peters, S. O., Ikeobi, C. O. N., Ozoje, M. O., Famakinwa, O.A., Oshodi, Y. S. and Adebambo, O. A. 2007. Egg quality of the Nigerian local chicken as influenced by some major genes. Nigeria Journal Animal Production, 34:25-31.

Rajkumar, U., Sharma, R. P., Rajaravindra, K. S., Niranjan, M., Red dy, B. L . N., Bhattacharya, T. K. and 
Chatterjee, R. N. 2009. Effect of genotype and age on egg qu a lit y traits in naked neck chicken under tropical climate of India. International Journal of PoultryScience, 8: 1151-1155

Silversides, F. G., Korver, D. R. and Budgell, K. L. 2006. Effect of strain of layer and age at photostimulation on egg production, egg quality, and bone strength.Poultry Science, 85: 11361144.

Tadesse, D., Esatu, W., Girma, M. and Tadelle, D. 2015. Comparative study on some egg quality traits of exotic chickens in different production system in East Shewa, Ethiopia.African Journal of Agricultural Research,10:10161021.

Tůmová, E. and Gous, R. M. 2012. Interaction between oviposition time, age, and environmental temperature on egg quality traits in laying hens and broiler breeders. Czech Journal of Animal Science, 57: 541-549.

Udoh, U. H., Okon, B. and Udoh, A. P. 2012. Egg quality characteristics, phenotypic correlations and prediction of egg weight in three (naked neck, frizzled feather and normal feathered) Nigerian local chickens. International Journal of Poultry Science, 11:696-699.

Vits, A., Weizenburger, D., Hamann, H., and Distl, O. 2005. Influence of different small group systems on production traits, egg quality and bone breaking strength of laying hens. First communication: Production traits and egg quality. Zuchtungskunde, 77:303-323. Waimaleongora-Ek, P., Garcia, K. M., No, H. K. and Ingram, D. R. 2009. Selected quality and shelf life of eggs coated with mineral oil with different viscosities. Journal of Food Science, 74:423-429.

Yakubu, A., Ogah, D. M. and Barde, R. E. 2008. Productivity and egg quality characteristics of free range naked neck and normal feathered Nigerian indigenous chicken.International Journal Poultry Science, 7:579-585.

Zaman, M.A., Ahmed, S. and Sutradhar, B. C. 2015. Study on the egg quality of abreed and $\mathrm{t} \mathrm{h} \mathrm{r}$ e e crossbreds at various ages under semi scavenging system on management. Pakistan Journal of Biological Sciences, 8:211-214.

Zita, L., Tůmová, E. and Štolc, L. 2009. Effects of genotype, age and their interaction on egg quality in brown-egglaying hens.ActaVet. Brno.,78:85-91.

Received: $17^{\text {th }}$ November, 2017

Accepted: $2^{\text {nd }}$ March, 2018 